\title{
Erratum to: Ein paläoökologischer Beitrag zum besseren Verständnis der natürlichen Vegetation der Schweiz
}

\author{
Erika Gobet • Elisa Vescovi · Willy Tinner
}

Published online: 11 February 2011

(c) Swiss Botanical Society 2011

\section{Erratum to: Bot Helv (2010) 120:105-115}

\section{DOI 10.1007/s00035-010-0080-2}

Due to a technical error, Figure 1 of this article was printed in black and white instead of in color. Please find the color figure below here.

Wegen eines technischen Fehlers wurde die Abbildung 1 dieses Artikels in schwarz/weiß gedruckt anstatt in Farbe. Hier folgt die Farbabbildung.

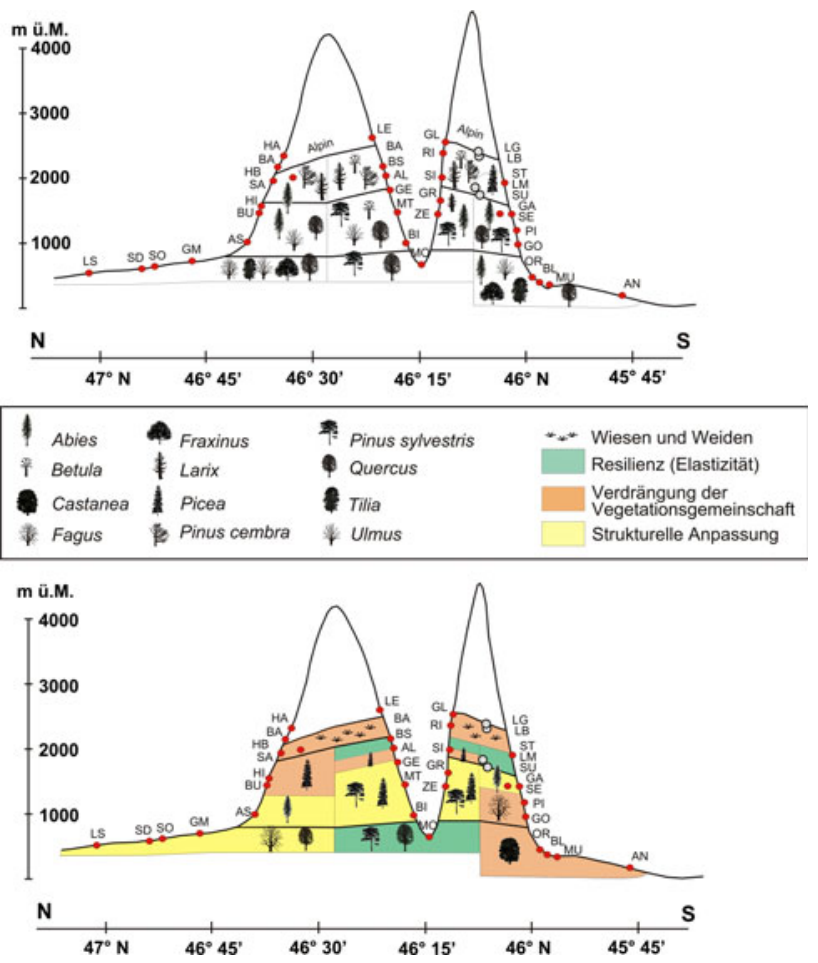

The online version of the original article can be found under doi:10.1007/s00035-010-0080-2.

E. Gobet $(\bowtie) \cdot$ E. Vescovi · W. Tinner

Oeschger Centre for Climate Change Research and Institute of Plant Sciences, University of Bern,

Altenbergrain 21, 3013 Bern, Switzerland

e-mail: erika.gobet@ips.unibe.ch

E. Vescovi

C.N.R., Institute for the Environmental Dynamics,

via Pasubio 5, 24044 Dalmine, Italy 